専門医症例報告

\title{
下顎前歯部咬耗による咀嚼機能障害の回復を図った症例
}

\author{
澤田＼cjkstart智史
}

\section{A Case Report of Prosthetic Rehabilitation for Mastication Disorder Resulting from Severe Attrition of Lower Anterior Teeth}

\author{
Tomofumi Sawada
}

抄 録

症例の概要：下顎前歯部咬耗を主訴に来院した 76 歳男性。口腔内検査および種々の検査より臼歯部の咬 合支持喪失による前歯部の過蓋咬合と低位咬合が疑われた。客観的な基準を参考に咬合の再構築を図り， 最終補綴処置に移行した。その後は 1 〜 カ月ごとの定期検診にて経過観察を行い，現在 5 年が経過した が良好な状態が保たれている。

考察：全顎的な咬合の再構築により，咀嚼機能および審美障害の改善を図ることができたと考えられる。 結論 : 本症例のように芷歯部欠損による咬合高径の低下と全顎にわたる著しい咬耗が認められる場合にお いて，セファログラム分析を参考にした咬合高径の決定により咬合の再構築することが重要であると考え られる。

和文キーワード

咀嚼障害，咬合高径，セファログラム分析，低位咬合

\section{ABSTRACT}

Patients: A 76-year-old male presented with a chief complaint of the severe attrition of lower anterior teeth. After examinations, the deep bite and loss of the vertical dimension of occlusion were caused by a defect in the occlusal support as a result of missing upper molars. A cephalometric analysis was employed to obtain objective criteria for the vertical dimension for prosthetic reconstruction. The prognosis was stable after 5 years with the periodic dental follow-ups every 1 to 6 months.

Discussion: Improvements in chewing ability and aesthetics were obtained with the occlusal reconstruction.

Conclusion: In this case of loss of the vertical dimension of occlusion and severe attrition, we believe that the cephalometric analysis was clinically important for determining the adequate vertical dimensions of the occlusion for occlusal reconstruction.

\section{Key words}

chewing disability, vertical dimension, cephalometric analyses, infraocclusion 


\section{I，緒言}

下顎前歯部の重度の咬耗による咀嚼機能障害をきたし た症例に対して, 全顎的な修復治療の必要性について説 明を行い，同意を得たうえで，セファログラム分析を参 考にした咬合高径の決定により咬合の再構築を図り良好 な経過が得られたので報告する。

\section{II. 症例の概要}

患者: 76 歳, 男性.

初診: 2005 年 3 月 26 日.

主訴：下顎前歯の咬耗が気になる。

全身的既往歴：高血圧症および不整脈の疑いよりバイ アスピリン服薬.

現病歴：10 年前から咬耗がひどくなり, 保健所にて 歯科相談をしたところ本院を紹介され来院した.

現症 : 初診時口腔内所見は, 上顎は (4)(3)(2) 1 (1)陶材 焼付鋳造ブリッジ，47 全部鋳造冠，76 5 6 局部床 義歯，下顎は $\overline{6}$ メタルインレー, $\overline{54 \mid 456}$ 全部鋳造 冠が装着されていた. $235, \overline{32} \mid 123$ に咬耗が認 められ，2|は根尖部に膿瘍形成が認められた（図 1). 顎関節や咀嚼筋に異常は認めず, 自覚症状もなかった。

検査結果：X線写真および歯周組織検査所見より，2 の歯根破折が認められた。その他の部位では全顎的に軽 度の水平性骨吸収を認めた（図 2,3)。頭部 X 線規格 写真を用いたセファログラム分析を行ったところ，上顎 に対する下顎の位置関係である Facial angle, APDI が 1 S.D.を超えて大ききこと, Convexityが 1 S.D.を超 えて小さいことからオトガイの突出を認め, LFH, ODI, Occlusal plane が小さいことから，咬合高径の低下， 下顎骨の前方回転，および過蓋咬合を認めた（図 4). さらに，術前検査として下顎運動検査から前方運動時お よび開閉運動時の終始運動経路の不一致が確認された (図 5)。咀嚼機能評価として, 咀嚼機能判定表から 20 品目に対して普通に食べられる割合の咀嚼機能スコ $ア^{1)}$ を算出したところ, 8 品目, スコア 0.4 であった.

診断：口腔内検査および種々の検査をもとに, 本症例 における問題点として前歯部の著しい咬耗, 上顎臼歯部 の欠損，および下顎の突き上げによる $2 \mid$ の歯根破折が 挙げられた。

以上のことから， 臼歯部の咬合支持喪失による前歯の 過蓋咬合および咬合高径の低下を伴う咀嚼障害と診断し た.

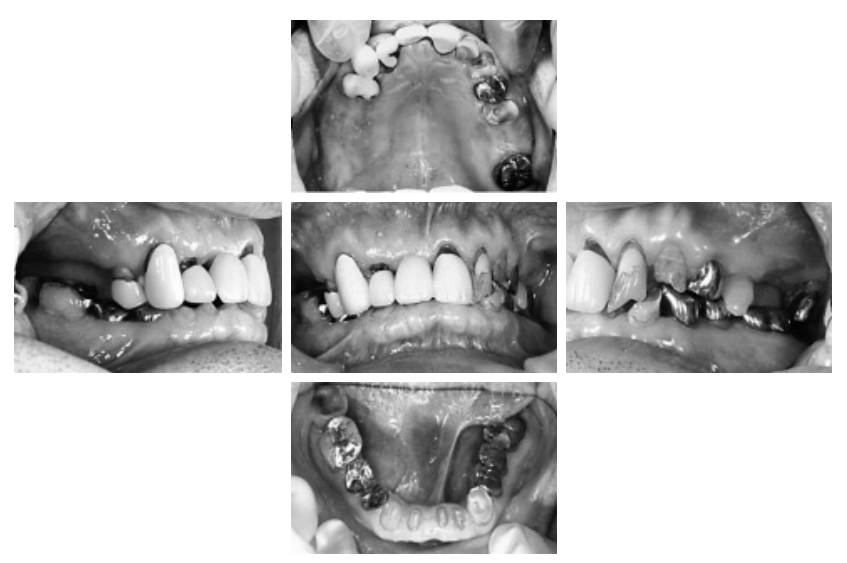

図 1 Intraoral views at first visit 初診時の口腔内写真

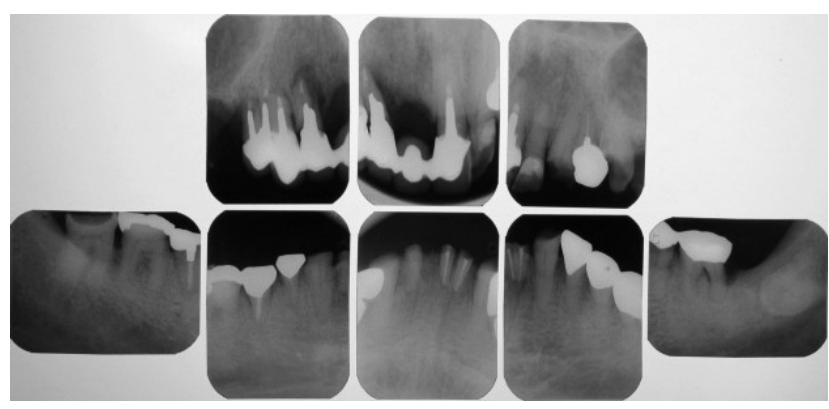

図 2 Dental radiographs at first visit 初診時のデンタル X 線写真

\begin{tabular}{|c|c|c|c|c|c|c|c|c|c|c|c|c|c|c|}
\hline Mobility & & & & 0 & 0 & 0 & & 0 & 0 & 0 & 0 & 0 & & 0 \\
\hline \multirow{3}{*}{$\begin{array}{l}\text { Probing } \\
\text { Depth }\end{array}$} & & & & 111 & \multirow{2}{*}{\multicolumn{3}{|c|}{ 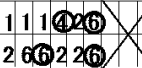 }} & \multicolumn{2}{|c|}{ 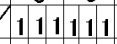 } & 212 & \begin{tabular}{l|l}
2 & 23 \\
\end{tabular} & 222 & \multirow{2}{*}{\multicolumn{2}{|c|}{\begin{tabular}{l|l|l}
$(3)_{2}$ & 3 \\
$(2) 2$ & 3
\end{tabular}}} \\
\hline & & & & 22 & & & & \begin{tabular}{l|l|l|}
2 & 2
\end{tabular} & 2) 22 & 2222 & $2|2| 3$ & \begin{tabular}{l|l|l|l|l|}
32 & 2
\end{tabular} & & \\
\hline & 7 & 6 & 5 & 4 & 3 & 2 & 1 & 1 & 2 & 3 & 4 & 5 & 6 & \\
\hline Probing & 3) 3 & 222 & 111 & 11. & $1|1| 1$ & 111 & & $1|1| 1$ & \begin{tabular}{l|l|l}
1 & 1 & 1 \\
\end{tabular} & \begin{tabular}{l|l|l|l|}
1 & 1 & 1
\end{tabular} & \begin{tabular}{l|l|l|l}
3 & 3 \\
\end{tabular} & 222 & 123 & \\
\hline Depth & (3) 3 & 232 & 11 & 11 & \begin{tabular}{l|l|l}
1 & 1
\end{tabular} & 111 & & \begin{tabular}{l|l|l|l} 
& 1 &
\end{tabular} & $\begin{array}{lll}1 & 1 & 1\end{array}$ & \begin{tabular}{|l|l|l|}
1 & 1 & 1 \\
\end{tabular} & 222 & 222 & 22 & \\
\hline Mobility & 0 & 0 & 0 & 0 & 0 & 0 & & 0 & 0 & 0 & 0 & 0 & 0 & \\
\hline
\end{tabular}

図 3 Examination of periodontal status at first visit 初診時の歯周組織検查

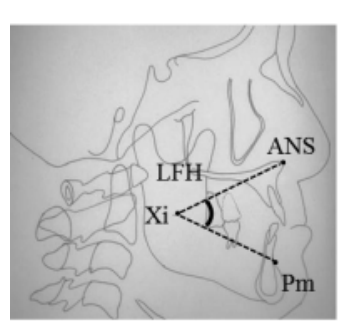

- Facial angle : $93^{\circ}$

- Convexity : $-4.5^{\circ}$

- APDI (Anterio-Posterior Displasia Indicator) : $90^{\circ}$

- LFH ( Lower Facial Height) : $45^{\circ}$

- ODI ( Overbite Depth Indicator) : $69^{\circ}$

- Occlusal plane : $1^{\circ}$

- U-1 to FH plane : $115^{\circ}$

- Closing Axis : $98^{\circ}$

図 4 Radiographic cephalogram analysis at first examination 初診時頭部 X 線規格写真分析 
a

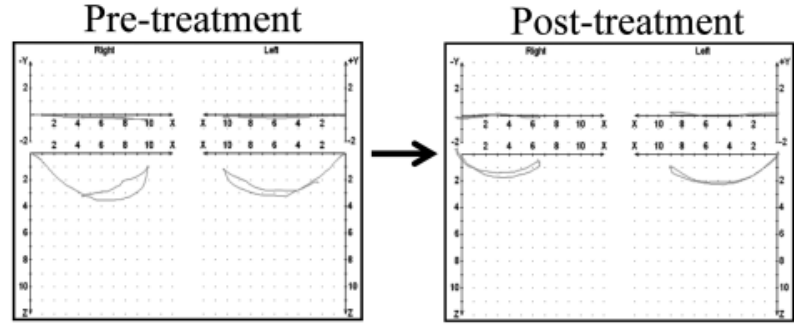

b

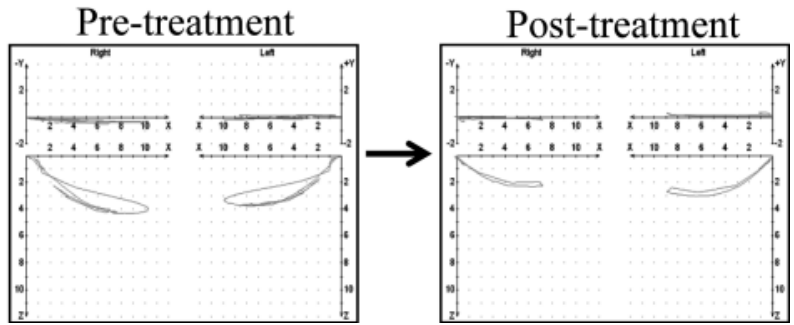

図 5 Mandible movement recordings, using the axiograph a: protrusion-retrusion movement, b: open-close movement left: pre-treatment, right: post-treatment 下顎運動検査

$\mathrm{a} ：$ 前後運動記録，b：開閉口運動記録

左：治療前，右：治療後

\section{III．治療内容と経過}

治療方針：5つの改善策として，(1)残存歯に対する歯 周治療，(2)歯根破折歯に対する抜歯による外科処置，(3) 著しい咬耗歯の抜髄による保存処置，(4)咬合の再構築， (5)最終補綴処置を揭げた。 上記内容について，患者に説 明を行い，同意が得られたので治療を開始した。

処置内容：咬合高径については頭部 X 線規格写真お よび下顎運動検査を参考に設定した，LFH が日本人男 性の平均 $49^{\circ}$ よりも $4^{\circ}$ 低いこと, $1^{\circ}$ 変化させるのに咬 合器上の切歯ピンを $2 \mathrm{~mm}$ 挙げる必要があることか ら, 切歯ピンを $8 \mathrm{~mm}$ 拳上した位置から咬合高径を決 定した。歯周初期治療を行いながら，上顎では使用中の 義歯を咬合の再構築を図るため治療用義歯として使用 し, 人工歯咬合面に即時重合レジンを添加し, 咬合高径 を拳上した，その後，上顎のテンポラリークラウンおよ びブリッジへの置換を行い，2|の抜歯を行った．また， 著しく咬耗している $\overline{32 \mid 3}$ および 3 の便宜抜髄と支台 築造を行った.さらに, 全顎的なテンポラリークラウン・ ブリッジの形態修正行いながら，プロビジョナルレスト レーションを作製し，再度，違和感等の症状がないこと を確認したうえで，上顎の最終補綴処置に移行した。咬 合床を用いた咬合採得および下顎のプロビジョナルを装

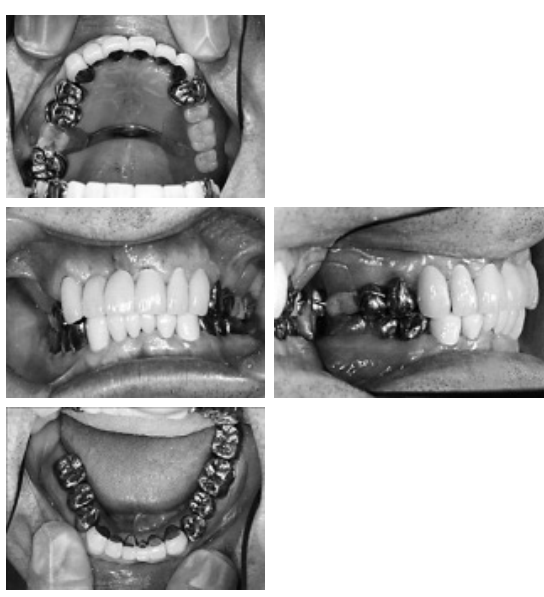

図 6 Intraoral views after insertion of final restoration 最終補綴装置装着時の口腔内写真

着した状態でのチェックバイトを用いて，(3) 2 1)(1)(2) 前装鋳造ブリッジおよび 457 全部鋳造冠を, $765 \mid 6$ の欠損部はピックアップ印象にて局部床義歯 （4|57を支台歯としたコバルトクロムによる屈曲鉤と 連結装置としてパラタルバーを用いたレジン床）を作製 して，同時に装着した。下顎に関しては，バーティカル ストップを確保するために, 456 に全部鋳造冠を, 続いて 7654 |に同様に全部鋳造冠を製作，装着した のちに前歯部に硬質レジン前装冠，ブリッジを装着した (図 6)。なお，咬合様式は下顎側方運動時の臼歯部負担 軽減を目的に左右とも犬歯誘導とした。初診時から補綴 装置装着までの治療期間は 1 年 8 力月を有した.

術後の経過および機能評価：術後のセファログラム分 析より, Facial Angle, Occlusal plane および LFH が 改善され，重称合わせのトレースからも，前方位にあっ た下顎位の後退と咬合高径の回復が確認できた(図 7).

下顎運動検査は術前では終始運動経路が一致していな かったものが，術後はその幅は小さくなり改善傾向にあ る（図 5)。また，咀嚼機能評価は咀嚼機能スコアが術 後には 17 品目, スコアが 0.85 に改善された。

最終補綴終了後は 1〜6 カ月ごとの定期検診で経過観 察を行い, 口腔清掃指導を行っている. 現在, 5 年以上 経過したが，一部前装部の摩耗か認められるものの予後 良好であり機能・装着感とも十分な満足度を得られてい る。

\section{IV. 考察}

咀嚼による機能的活動のみならず，下顎運動や口腔衛 生環境など様々な要因が影響して咬耗が生じる ${ }^{2)}$ 。咬耗 


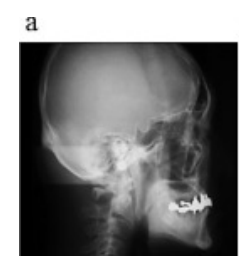

b

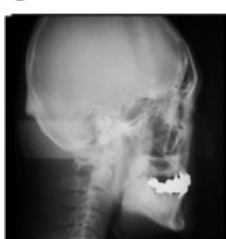

c

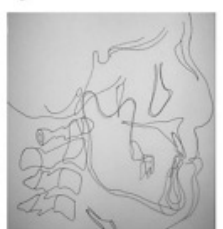

- Facial angle $\left(84.83^{\circ} \pm 3.05^{\circ}\right)$

Pretreatment $93^{\circ} \rightarrow$ Post-treatment $88^{\circ}$

- Convexity $\left(+7.58^{\circ} \pm 4.95^{\circ}\right)$

Pretreatment $-4.5^{\circ} \rightarrow$ Post-treatment $1^{\circ}$

- APDI $\left(81.04^{\circ} \pm 4.4^{\circ}\right)$

Pretreatment $90^{\circ} \rightarrow$ Post-treatment $84^{\circ}$

- $\mathrm{LFH}\left(49^{\circ} \pm 3.05^{\circ}\right)$

Pretreatment $45^{\circ} \rightarrow$ Post-treatment $49^{\circ}$

- ODI $\left(72^{\circ}\right)$

Pretreatment $69^{\circ} \rightarrow$ Post-treatment $71^{\circ}$

- Occlusal plane $\left(13^{\circ}\right)$

Pretreatment $1^{\circ} \rightarrow$ Post-treatment $10^{\circ}$

- U-1 to FH plane $\left(113.13^{\circ} \pm 5.54^{\circ}\right)$

Pretreatment $115^{\circ} \rightarrow$ Post-treatment $114^{\circ}$

- Closing Axis $\left(78^{\circ}\right.$ )

Pretreatment $98^{\circ} \rightarrow$ Post-treatment $97^{\circ}$

図 7 Radiographic cephalogram analysis at the pretreatment and post-treatment (mean \pm S.D.)

a: pre-treatment; b: post-treatment; c: tracing of radiographic cephalogram analysis the pretreatment and post-treatment

初診時と治療後の頭部 X 線規格写真分析 (平均士標 準偏差)

$\mathrm{a}$ ：初診時, b : 治療後, $\mathrm{c}$ ：初診時, 治療後の重ね 合わせトレース

による低位咬合に対して，生体に調和した咬合の再構築 を図るうえで，セファログラム分析による客観的な指標 を用いた咬合高径決定方法の有効性か蕔告されている ${ }^{3)}$.
本症例においても適切な咬合高径の回復および臼歯部 での咬合確立が咀嚼機能および審美障害の改善へとつな がったと考えられる。

\section{V. 結 論}

一般的に患者の口腔内は機能面・審美面において経時 的に変化する場合がある．特に，本症例のように上顎臼 歯部欠損による咬合高径の低下と全顎にわたる著しい咬 耗が認められる例においては，咬合再構築するうえでセ ファログラムの分析を参考にした咬合高径の決定が重要 であると考えられる。

\section{文献}

1）佐藤裕二, 石田栄作, 皆木省吾, 赤川安正, 津留宏道. 総 義歯装着者の食品摂取状況. 補綴誌 1988; 32: 774-779.

2) Johansson A, Johansson AK, Omar R, Carlsson GE. Rehabilitation of the worn dentition. J Oral Rehabil 2008; 35: 548-566.

3) 堀 紀雄. 低位咬合に対する補綴的アプローチの 1 症 例. 補綴誌 2006; 50:573-576.

著者連絡先：澤田 智史

干238-8580 神奈川県横須賀市稲岡町 82

Tel: 046-822-8861

Fax: 046-822-8861

E-mail: tomofumi@kdcnet.ac.jp 